\title{
Avaliação Microbiológica de Sucos Naturais Oferecidos em Uma Escola Privada de Cuiabá - MT
}

Jállisson Jones (I), Bianca Pereira (I), Janaina Ketelly (I), Melissa

Schirmmer (I), Marcia Americano (I)

(I) UNIC - UNIVERSIDADE DE CUIABÁ (Av. Manoel José de Arruda n 3.100 )

\section{Resumo}

Os sucos naturais oferecem uma enorme quantidade de vitaminas, especialmente a vitamina $\mathrm{C}$, e sais minerais que o organismo necessita, contribuindo para o bom estado do mesmo. É uma bebida de fácil preparo possibilitando a oferta e a comercialização em grandes quantidades. A contaminação e deterioração dos alimentos por microrganismos nas cozinhas das escolas estão ligados a diversos motivos, entre eles: à falta de higiene sanitária, treinamento não adequado dos funcionários para manipulação dos alimentos, não utilização correta dos EPIs obrigatórios e o não uso de água tratada. Os sucos apresentam fatores que contribuem para a proliferação dos microrganismos, sendo, portanto necessário o emprego das boas práticas de fabricação para se evitar doenças transmitidas por alimentos (DTA). O presente estudo objetivou avaliar a qualidade microbiológica dos sucos in natura de acerola, maracujá, uva, tangerina e caju oferecidos aos alunos de uma escola privada de Cuiabá - MT. Durante 5 dias do mês de junho de 2014 coletou-se 5 amostras de cada lote de suco, totalizando 25 amostras, para a realização das análises microbiológicas de contagem de coliformes totais, coliformes a $45^{\circ} \mathrm{C}$ e pesquisa de Salmonella spp por serem as bactérias indicadoras da qualidade higiênico-sanitária de sucos in natura, segundo a RDC 12 de janeiro de 2001. Das 25 (100\%) das amostras analisadas 15 (60\%) dos sucos de uva, cajú e tangerina apresentaram contagens de coliformes totais, a presença deste grupo de bactérias indicam problemas com as condições higiênicas durante a produção destes alimentos, porém este grupo de bactérias não representa

\footnotetext{
Referência:

Jállisson Jones, Bianca Pereira, Janaina Ketelly, Melissa Schirmmer, Marcia Americano. Avaliação Microbiológica de Sucos Naturais Oferecidos em Uma Escola Privada de Cuiabá - Mt. In: Anais do 12 Congresso Latinoamericano de Microbiologia e Higiene de Alimentos - MICROAL 2014 [= Blucher Food Science Proceedings, num.1, vol.1]. São Paulo: Editora Blucher, 2014. 
riscos à saúde do consumidor. Nas 10 (40\%) amostras de suco de maracujá e acerola não se detectou a presença de coliformes totais. Em relação à contagem de coliformes a $45^{\circ} \mathrm{C}$ em $25(100 \%)$ das amostras de sucos analisadas não apresentaram este grupo de bactérias. Em nenhum dos lotes de suco avaliados isolou-se bactéria do gênero Salmonella spp. Conclui-se que os sucos de frutas oferecidos aos alunos estão dentro dos padrões microbiológicos preconizados pela legislação brasileira, não oferecendo risco a aquisição de DTAs.

Palavras-Chave: Sucos, Coliformes totais, Coliformes à $45^{\circ} \mathrm{C}$, Salmonella spp

\section{Agência de Fomento:}

